\title{
TERRITORIAL NATURE PROTECTION IN THE FORMER MILITARY TRAINING TERRITORY RALSKO
}

M. Hon c ů: Territorial nature protection in the former military training territory Ralsko. - Geografie - Sborník CGS, 103, 3, pp. 356 - 361 (1998). - In the region of the former military training territory Ralsko 11 small scale protected areas were declared. One of them belongs to the national nature reserve category, three to the nature reserve category and seven protected areas were placed in the nature monument category. The paper contains a detailed overview of all 11 declared small scale protected areas, three temporarily protected areas and proposals for some localities to be declared as protected. KEY WORDS: former military training territory Ralsko - small scale protected areas national nature reserve - nature reserve - nature monument.

\section{Břehyně-Pecopala}

The locality is part of the "Doksy and the mountain range Kummer region" a protected area since 1933, a state nature reserve since 1967 and a national nature reserve since 1992. The Břehyně part was declared in 1991 to be a moor of international importance (Ramsar convention) and in 1993 to be a biogenetic reserve of the European Community. The locality forms part of the proposed national nature reserve "Doksy sandstones and wetlands".

The largest small scale protected area in Česká Lípa district with a spread of 903,5 ha, one of the most important areas from a naturalistic point of view in northern Bohemia, it represents the core of the future National nature reserve Doksy sandstones and wettlands. It is formed from two different landscape types.

One of them is Břehyně fishpond ( $90 \mathrm{ha}$ ) the origin of which is dated back to 14 th century. It was founded in a place of vast peaty marshes. Water species such as Nymphaea candida, Caulinia minor and Najas marina could be found there. In the surroundings of the fishpond with peatbogs and wetland pine woods (altogether $502 \mathrm{ha}$ ) characteristic plant species are to be found: Eriophorum vaginatum, Ledum palustre, Andromeda polifolia, Dactylorhiza incarnata subsp. serotina, Hammarbya paludosa, Drosera rotundifolia and Rhynchospora alba. This part is protected within the bounds of the Ramsar convention for conservation of wetlands and for protection of water and swamp bird species of European importance. Nesting of Grus grus, Haliaeetus albicilla, Botaurus stellaris, Gallinago gallinago and other species has been found In this national nature reserve 264 bird species have been detected by long-term exploration.

The second part of the reserve is formed from the sandstone mountain range Pecopala (401,5 ha) pervaded by the basalt knob of Pecný Hill. The hilltop part is covered by primeval beech forest. Of especially protected species, Rosalia alpina has been found and bird species such as Glaucidium passerinum and Ficedula parva. Remarkable flora is to be found there - 
vegetation of flower-rich beech woods with Lycopodium anotinum and Huperzia selago. On the former tank road at the southern foot of Pecopala two critically endangered crustacea species, Triops cancriformis and Branchipus schaefferi, appear in occasional puddles.

\section{Velký a Malý Bezděz (High and Low Bezděz Hill)}

The state nature reserve Malý Bezděz Hill was declared in 1949. In 1993 the nature reserve was then enlarged to a spread of 29,06 ha by the incorporation of Velký Bezděz Hill (Bezděz cadastry). The locality dominates the south-east edge of the area. The phonolite double-hill is forested by mixed deciduous vegetation which comes into pure beech woods on debris. Hilltops, sunny hillsides and rocks are occupied by thermophile species of exposed location flora: Dianthus gratianopolitanus, Stipa joannis, Anthericum ramosum and Epipactis atrorubens. It is one of the few localities in Bohemia where Rosalia alpina and Necydalis ulmi are to be found. There is a very remarkable occurence of Salamandra salamandra of amphibian species. At the northern foot of Velký Bezděz hill there is a fissure form ice cave.

\section{Hradčanské rybníky (Hradčanské fishponds)}

Hradčanské fishponds have been part of "Doksy and the mountain range Kummer region" protected area since 1933. The nature reserve was declared in 1992 with an area of 144,65 ha (Hradčany cadaster). The locality is part of the proposed National nature reserve Doksy sandstones and wetlands.

They are four fishponds, built in 15th century, on the Hradčanský brook: Černý, Vavrouškův, Strážovský Držník and the inflow part of Hradčanský fishpond. In spite of the damage done by the Soviet army the fishponds with contiguous peatlands, wet meadows and forest vegetation represent a precious area of natural beauty. Of important flora species, Andromeda polifolia, a vast growth of Ledum palustre, Calla palustris and Potamogeton alpinus are to be found as well as the nesting place of water birds. The dams of some fishponds are damaged. The Strážovský fishpond is overgrown with the fall of tree seeds and its dam is entirely destroyed. The surroundings of Vavrouškův fishpond and Držník suffered from heavy fire in 1991. During entomological exploration in 1989 - 1993 the occurence of 698 butterfly species was registered.

\section{Ralsko Hill}

Ralsko Hill has been a state nature reserve since 1967. The nature reserve was declared in 1992 with an area of 18,15 ha in Stráž pod Ralskem and Noviny pod Ralskem cadastry.

It is a basalt hill (an altitude of $696 \mathrm{~m}$ above sea level), the highest point of the hill of the same name, an isolated hillyland of a mountainous nature with steep rock slopes, hill debris and flowing opening of cold air. In addition to relict vegetation of limes there are flower-rich beech woods with maple on the hilltop with Lunaria rediviva, on the exposed rocks Woodsia ilvensis, Allium strictum and recently disappeared Aster alpinus. Blechnum spicant is to be found in inversive shady locations. Besides the foothill and mountainous species of invertebrates represented for example by Rosalia alpina, the thermophile Poecilonota rutilans is to be found and from vertebrates Bubo bubo, Salamandra salamandra and Triturus montanus. 


\section{Vranovské skály (Vranovské rocks)}

The nature monument was declared in 1993 in Noviny pod Ralskem cadastry with an area of 17,92 ha. The slope rock city is formed from calcareous sandstones forested by relict pine woods. Fortified sandstones create overhangs, windows and four rock mushrooms. The most important rock is Julia's viewpoint (named after the countess Julie Hartigová who lived in the first half of 19th century). On the rocks there is flora of great significance - Arctostaphyllos uvaursi and especially Carex pediformis subsp. macroura which is found in Hradčanské walls as well - the only two sites in Central Europe.

\section{Rašeliniště Černého rybníka (The peatbog of Black fishpond)}

The nature monument was declared in 1995 with an area of 4,26 ha in Stráž pod Ralskem and Hamr na Jezeře cadastry. It includes open water area with not large vegetation of dragged Nymphea alba and on one side wet peaty meadows and pine woods with relict plant and animal species. Drosera rotundifolia, Oxycoccos palustris, Eriophorum vaginatum and Pyrola minor are to be found there. As a representative of remarkable insect species we can name at least Anax imperator.

\section{Široký kámen (The Broad stone)}

The nature monument was declared in 1995 in Hamr na Jezeře cadastry with an area of 29,81 ha. The locality represents a rare geomorphological formation in the Czech cretaceous formation, a typical table rock. Of plant species of great significance, protected Ledum palustre is to be found there. Falco peregrinus nested there in the past but Bubo bubo appeared instead. At present the regular nesting of Corvus corax is reported.

\section{Stohánek}

The nature monument was declared in 1995 in Svéborrice cadastry with an area of 26,31 ha. Stohánek is an isolated rocky formation of mesa type. Thermophile flora is represented by e.g. Gerantium sanquineum. A place with a very interesting history. The remains of a small fort, the stairs and the residence of a hermit are preserved there.

\section{Malý a Velký Jelení vrch (Little and Great Deer hill)}

The nature monument was declared in 1995 in Svébořice cadastry with an area of 7,91 ha. It is a basalt double-hill forested by flower-rich beech woods with coniferous woods on debris. On rocks and nubbins thermophile species such as Woodsia ilvens are to be found. In lower locations the occurance of protected Cephalantera damasonium has been registered. Rare species of insect have been noticed in the locality.

\section{Děvín, Ostrý and Schachtstein}

The nature monument was declared in 1995 in Hamr na Jezeře cadastry with an area of 33,1 ha. There are extreme relief forms with preserved and balanced formations of natural composition. The occurence of rare flora and 
fauna at Děvín and Ostrý, Cephalantera rubra and Carabus limei are to be found. At the top of Děvín hill there are the remains of a royal castle. Two adits show mining in the past (extraction of iron ore). Although the adits are relatively short they serve for several species of bat to winter.

Schachtstein reflects the methods of mining in the Middle Ages. Extracted vein of polzenite iron ores reach a depth of approximately $10-12 \mathrm{~m}$ at one place. There are the traits of pit tips. The ore deposits were of economic importance in the Middle Ages. The scatter of deposits and their small stocks are not of interest for economic use.

\section{Divadlo (Theatre)}

The nature monument was declared in 1995 with an area of 2,45 ha. in Hamr na Jezeře cadastry as a sporadic geomorphological formation forested by original pine woods. The occurence of rare thermophile plants e.g. Scorzonera purpurea was reported in the past but is not found at present.

\section{Hamerský rybník a Děvínská louka (Hamerský fishpond and Děvínská meadow)}

The area, of 139 ha (Hamr na Jezeře cadastry), has been proposed to be protected as a nature reservation.

The area represents the inflow part of the fishpond and adjacent peatbog of Děvín meadows. The fishpond was drained for a long time (1984 - 1994) as a result of uranium mining. A small ecological terrace prevented the destruction of the most valuable part of the peatbog. Flora is of the boreal character. Besides Andromeda polifolia, Ledum palustre, Potamogeton alpinus and Rhynchospora alba as well as Dryopteris cristata, Epipactis palustris and some other particularly protected plant species can be found there. Altogether 30 protected plant species have been found. Mountainous Carabus linnei descends there to an altitude of $305 \mathrm{~m}$ above sea level. The open water level is important for the nesting of a number of water birds. In the locality there are tussocks or so-called thufurs, small spring area lakes in artesian points of issue of Turonian water. The occurence of two ecotypes of spruce is interesting.

\section{Hradčanské stěny (Hradčanské walls)}

Hradčanské walls have been part of the "Doksy and the mountain range Kummer region" protected area since 1933. A temporarily protected area was declared in 1993 in Veselí, Brenná and Hvězdov cadastry. They are the part of proposed National nature reserve Doksy sandstones and wetlands.

Hradčanské walls represent one of the most valuable regions of the Czech basin due to the occurence of relict vegetation on the nubbins with calcareous sandstones. Approximately 20 protected endangered, even critically endangered, flora species of Czech Republic are to be found there. There is the unique occurence (in Bohemia) of Minuartia caespitosa, Chimaphila umbellata, Carex pediformis subsp. macroura and Astralagus arenarius. It is peculiar that the thermophile Pannonian species such as Pulsatilla patens and Pulsatilla pratensis subsp. bohemica blend with dealpine ones e.g. Thesium alpinum and Biscutella laevigata subsp. varia. The geomorphological formations such as rock towers, rock gates, capstones etc. but as well as the traits of mining of iron ores in the Middle Ages are of the great significance. 
The nesting place of Bubo bubo and Corvus corax gives to the locality a higher degree of importance.

\section{Údolní niva Ploučnice (Fluvian plain of the Ploučnice River)}

A temporarily protected area was declared in 1993 in Veselí, Brenná and Hvězdov cadastry. The area is part of the proposed National nature reserve Doksy sandstones and wetlands.

It is a well-preserved fluvial plain (created in Quaternary - holocene) of Ploučnice river which meanders between Boreček and Veselí. There are several natural biocentres connected with the biocorridor. The ecosystem of wet meadows is known for protected flora e.g. Iris sibirica, Dactylorhiza majalis, Pedicularis palustris, Hottonia palustris and others. Some rare animal species can be seen such as Lutra lutra, locally even Astacus fluviatilis.

\section{Ploužnické mokřady (Ploužnické wetlands)}

A temporarily protected area in Hvězdov and Dolní Okna cadastry with an area of 43 ha in total. It includes the plain of Ploužnice river and Ploužnický brook between the villages of Hvězdov and Dolní Okna. The bog plain of Ploužnický brook represents a balanced ecosystem, contains several biocentres and serves as a biocorridor as well. The significant flora species: Dactylorhiza majalis, Salix repens, Menyanthes trifoliata and Lingularia sibirica. The latter was to be found in the past. In the recent years Grus grus stayed and probably nested there as well. Ciconia nigra makes flights into the locality for food.

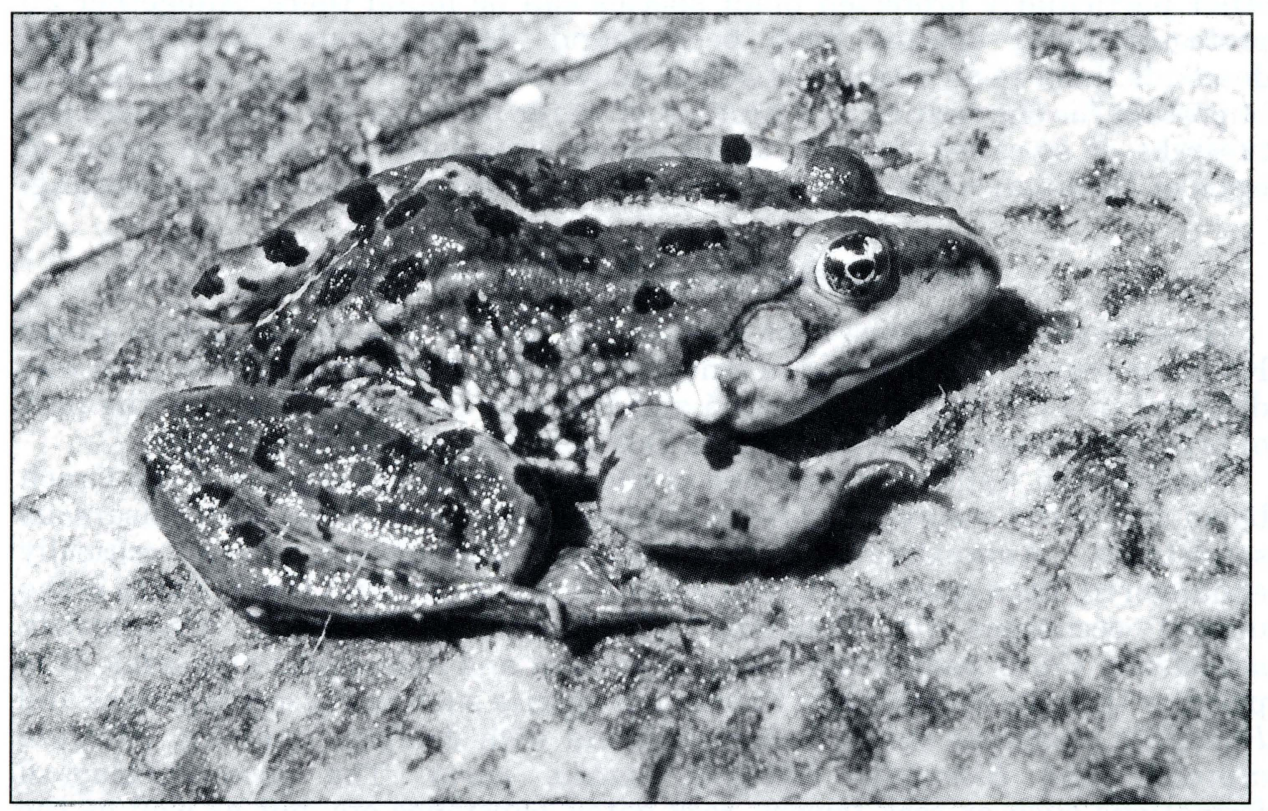

Fig. 1 - Rare species of a frog Rama ridibunda plentifully occured on whole former military training area Ralsko. Photo by Z. Vitáček. 


\section{Rašeliniště Pustý rybník (The peatbog of Pustý fishpond)}

A moor of regional importance with an area of approximately 320 ha in Hradčany cadastry. It is a part of the proposed National nature reserve Doksy sandstones and wetlands.

It is one of the localities of great significance in Jestřebsko-hamerské basins. Its area belongs amongst the biggest. There is a classic vegetation of peaty pine woods with Oxycoccos palustris, Andromeda polifolia, Eriophorum vaginatum and Vaccinium uliginosum. The local ecotype of Pinus sylvestris is to be found. Fauna is represented by Cervus elaphus, Lacerta vivipara is wide spread, Grus grus flies in from the surrounding localities for the purpose of food. Of the intervertebrates Carabus arcensis, Carabus problematicus and Cicindela sylvatica have been detected. The peatbog is a watershed between Hradčanské fishponds and Břehyně fishpond. From the point of view of natural science the locality suffered from drainage and the insertion of melioration ditches. The peatbog length is approx $2 \mathrm{~km}$, the width approx 800 $\mathrm{m}$ and the heigth of the peat layer is $235 \mathrm{~cm}$. According to Z. Dohnal (1960) this peatbog is the only one in the region with continuous natural development.

\section{Průrva Ploučnice v Novinách pod Ralskem (The ravine of Ploučnice river in Noviny pod Ralskem)}

The area in the Noviny pod Ralskem cadastry is proposed to be a technical monument. It is approx $100 \mathrm{~m}$ long, 3.5 wide and $7 \mathrm{~m}$ tall ravine. It continues then in an underground tunnel built in 17th century (mentioned by Balbín in 1680) which served as the penstock of a defunct fishpond.

\section{Velká a Malá Buková (Little and Great Buková Hill)}

It is a significant landscape element with an area of 92,5 ha which is part of the proposed National nature reserve Doksy sandstones and wetlands.

The locality can be described as the remains of primeval forest of hilltop beech wood located on both hills of eruptive origin with transition to oak woods on the south-west slope of Malá Buková Hill. In the tophill nubbins the isolated remains of postglacial calcareous soils vegetation are to be found, represented by Lilium martagon, Hepatica trilopa and others. At the western sandstone buttress there is a sporadic occurence of Ledum palustre. Forest fauna predominates: Cervus elaphus, Dama dama, Ovis musimon, Capreolus capreolus and wild boar. Of protected fauna species, the occurence of critically endangered Rosalia alpina has been found, the occurence of Upupa epops has been reported and in 1996 Ciconia nigra nested there. The outcrops of calcareous sandstones under the tophill of Malá Buková Hill are remarkable. There have been findings of not well-preserved fossils of Pecten laevis and Cardiola sp.

(The author is with the District Museum, náměstí Osvobození 297, 47001 Česká Lípa.)

Arrived at the editors office on May 25, 1998

Recommended for publication by Václav Poštolka and Zbyněk Ryšlavý 